
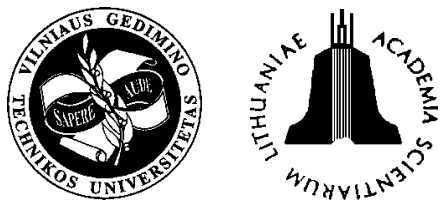

ISSN 1648-4142 TRANSPORT

http:/www.vtu.lt/english/editions

\title{
THE COMPARATIVE ANALYSIS OF LITHUANIAN AND LATVIAN TRANSIT TRANSPORT
}

\author{
Ramūnas Palšaitis ${ }^{1}$, Darius Bazaras ${ }^{2}$, Gintautas Labanauskas ${ }^{3}$ \\ Dept of Transport Management, Vilnius Gediminas Technical University, \\ Plytines g. 27, LT-10105 Vilnius-16, Lithuania. Tel.: 2744776 \\ Received 2003-11-05; accepted 2004-01-15
}

\begin{abstract}
The results of the comparative analysis of Lithuanian and Latvian transit transport show that transit transport systems of these countries compete against each other. Latvia has evidently better developed harbours, which are able to process bigger scopes of loads. In comparison with Lithuanian transit transport system, Latvia has the competitive advantages, which are determined by its historical and trading relations, infrastructure, socio-cultural environment and traditions as well as more favourable integration with other systems of transport. In this article general indicators of sea and railroads transit transport as well as the problems, which impede the development of transport system, are analysed. It is suggested to pay attention to the proposed strategic directions of transit services development as well as to solve (on the governmental level) the questions of competition choosing the cooperation policy of Lithuanian and Latvian systems of transit transport.
\end{abstract}

Keywords: transit, transport, harbours, competitive.

\section{Introduction}

The geographical situation of Lithuania and Latvia as well as historically emerged relations of international marketing determine an important role of these countries in the market of transit services (especially on the trend of East-West - working with the flows of goods between the countries of CIS and the countries of Western Europe). In 2002 the contribution of the service sectors reached nearly $8 \%$ of GDP in Lithuania and over $12 \%$ in Latvia. In both Baltic countries, implementing the goals of transit business development, it is aspired to shape the working environment which would be attractive by its technical, technological, organisational and juridical aspects as well as to secure trusted and safe conveyance of the loads. Striving to raise the transit loads, these factors determine the severe competition between Lithuanian and Latvian harbours. Not only the prise, but the quality (in all the circuit of the services of the logistics especially emphasizing the factor of the modern technologies of transport) becomes more relevant aspect of this competition on the international markets $[1,2]$. Consequently the creation of the legal basis, which would be auspicious for the activities, has a great influence on the stability of transit flows. It could

\footnotetext{
1 E-mail: trvadyba@ti.vtu.lt

2 E-mail: dbazaras@one.lt

3 E-mail: glabas@centras.lt
}

be done only harmonising two contradictory interests of the state: on the one hand it must be pursued to create liberal conditions to force the transport flows, on the other hand - the way for the illegal transport flows must be blocked up.

In both countries harbours are the main points of transit attraction as well as centres of railway transport and water transport interaction. The scope of transit conveyances via Lithuanian and Latvian railways [3-6] depends on the distribution of the loads between the harbours mentioned above.

\section{The analysis of the harbour activities}

Klaipeda is an attractive harbour for transit. It connects the transport corridors between East and West. Klaipeda is the most distant to the East non-freezing harbour in the watershed of the Baltic Sea. The depth of the boundaries and the prefatory channel (in the northern part of the harbour) is 14,5 metres, and in the future the depth must reach 17 metres. The harbour of Klaipeda is the single national harbour of Lithuania - one of the most important objects of the state transport, multimodal harbour with different tendencies, grounds and possibilities.

The harbour of Klaipeda connects the land roads, railroads and water roads between East and West. The near land roads to the most important industrial regions 
of Eastern countries (Russia, Byelorussia, Ukraine, etc.) are driven from this place.

The harbour of Klaipeda is connected by constant navigation lines with Germany, Sweden, Denmark, Netherlands, United Kingdom, Belgium, Russia, Poland, Ecuador, Costa Rica, Morocco, Southern Korea, USA and Canada.

The main navigation lines to the harbours of Western Europe, South-eastern Asia and America drive through the harbour of Klaipeda as well. Many sea lines connect Klaipeda with the United States of America, Canada, Southern America, Africa and other places of the world. The ferries navigate to: Kiel, Mucran, Carlshamn, Ahus, Aarhus, Aabenraa, Travemunde, Copenhagen, Fredericia, Antwerp, Hull, Felixstowe, Bilbao, Rotterdam, etc.

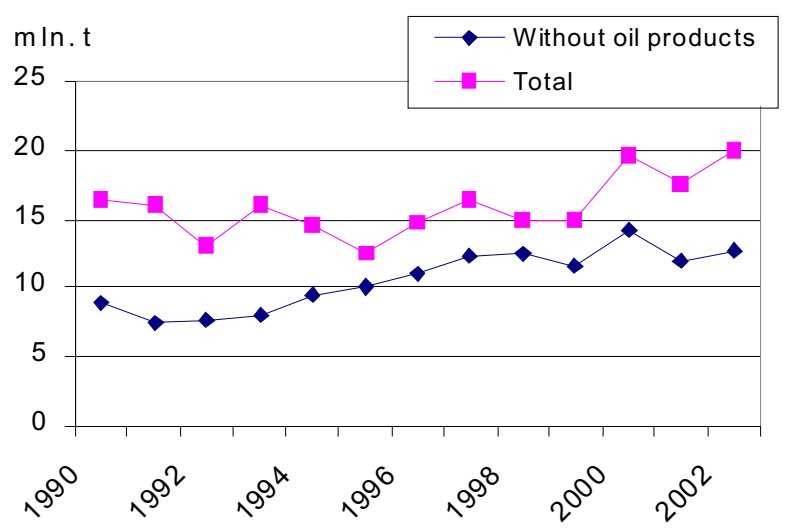

Fig 1. The scopes of the loadings in the harbour of Klaipeda (during 1991-2002). The source of information: the directorate of the national harbour of Klaipeda

The main loads, which are being loaded into the ships are: oil products, manure, Ro-Ro loads, metals and ferroalloys, wood, scrap-iron, grain, cement.

The main loads, which are being unloaded from the ships are: Ro-Ro loads, minerals, containers, sugar, shortlived commodities, coarse forage (Fig 1, Table 1).

Table 1. The distribution of the loads according to the type (in 2002)

\begin{tabular}{|c|l|c|c|}
\hline \multicolumn{1}{|c|}{$\begin{array}{c}\text { The type of the } \\
\text { load }\end{array}$} & $\begin{array}{c}\text { Thousands of } \\
\text { tons }\end{array}$ & $\begin{array}{c}\text { The part of } \\
\text { general loading, } \\
\%\end{array}$ \\
\hline 1 & fluid & 7980,7 & 40,5 \\
\hline 2 & powdery & 5703,2 & 28,8 \\
\hline 3 & general & 6058,8 & 30,7 \\
\hline 3A & it makes (3): Ro-Ro & 2556,0 & 12,9 \\
\hline 3B & in containers & 730,7 & 3,7 \\
\hline 3C & other general & 2772,1 & 14,1 \\
\hline
\end{tabular}

The source of information: the directorate of the national harbour of Klaipeda.
In 2002 in the harbour of Klaipeda 130560 of RoRo units (land road devices and loads) have been transhipped; it makes $3 \%$ less than in 2001 . It has been reloaded $1 \%$ more (than in 2001) land road devices, and the loading of the loads decreased by very $53 \%$, up to 4688 units. In 2002, the main part of Ro-Ro loads (66,6 \% of land road devices and all loads) has been reloaded in the international sea-passing, which is being operated by KLASCO.

In 2002, 71609 TEU containers were reloaded in the harbour of Klaipeda; it makes $40 \%$ more than in 2001. After the end of an economical crisis, the loadings of the containers are rapidly increasing since 1999 (Fig 2).

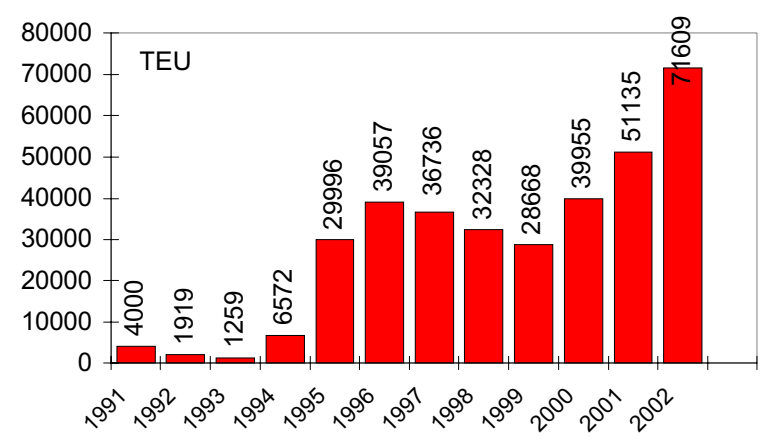

Fig 2. The dynamics of the loadings of the containers in the harbour of Klaipeda. The source of information: the directorate of the national harbour of Klaipeda

The national harbour of Klaipeda is the only commercial harbour in Lithuania; however, not only the harbours of Latvia and Estonia, but the harbours of Kaliningrad, St. Petersburg as well as the eastern harbours of Poland are its very strong contenders.

A few bigger harbours of the Baltic Sea region could be mentioned. They are: Tallinn, Ventspils, Riga, Liepoja, St. Petersburg, Kaliningrad. The depth of the harbour is one of the main reasons of its attractiveness.

The proportion between the territory of the harbour and the length of the boundaries is the other important physical factor which shows what area falls to one meter of the boundary. In comparison with other harbours of the Baltic Sea region, this proportion is the least in Klaipeda. The lack of storage territories increases together with the increase of the depth along the boundaries; therefore it is evident, that the territory of the harbour should be widened.

The harbour of Klaipeda impends the harbours of Riga and Tallinn (to the scope of the loadings of the containers), but it evidently stands behind the harbour of St. Petersburg - over half a million TEU containers a year are being reloaded in it. Russia promotes the transportation of Russian loads through the harbour of St. Petersburg in every possible way. It is forecasted, that the circulation of one million TEU containers through this harbour will be reached soon. However such concentra- 
tion of the work causes the problems such like the transportation of containers through the city of St. Petersburg, the safety of the loads, etc.

In the harbour of Klaipeda 8 lines of the reload of the containers are in action now. The flow to Germany (exactly to Hamburg and Bremenhafen) gets $65 \%$ of the loadings - the dominant part of the flow. Other countries (Belgium, Netherlands, United Kingdom and Denmark) have a stress of less importance. Consequently the biggest flows of the containers go to the main European harbours: Hamburg, Bremenhaven, Antverpen (Table 2).

Table 2. The loadings of the containers in the harbours of the Baltic Sea region, TEU

\begin{tabular}{|l|c|c|c|c|}
\hline & 2001 & 2002 & $\begin{array}{c}2002 / 2001, \\
\%\end{array}$ & $2002-2001$ \\
\hline St. Petersburg & 478659 & 580639 & 21.3 & 101980 \\
\hline Tallinn & 78072 & 87912 & 12.6 & 9840 \\
\hline Ventspils & 0 & 1044 & - & 1044 \\
\hline Riga & 101023 & 127459 & 26.2 & 26436 \\
\hline Klaipėda & 51135 & 71589 & 40.0 & 20454 \\
\hline Kaliningrad & 21313 & 27871 & 30.8 & 6558 \\
\hline Total & 730202 & 896514 & 22.8 & 166312 \\
\hline
\end{tabular}

The source of information: the directorate of the national harbour of Klaipèda.

Evaluating the perspectives of the development of transit through harbours, it is necessary to stress, that the competition will continue to grow. The Russian reorientation to its own harbours is already being developed. In this context, the decision of Transit committee to improve the policy of rates of the railroads and an effective realisation of the project $2 \mathrm{~K}$, should prompt to secure the favourable conditions for the transportation of the loads from Russia to the harbour of Klaipeda. Besides it is very important to attract the transit of the loads from other Eastern countries (especially Byelorussia, Ukraine and Kazakhstan) to Lithuania.

It is necessary to notice, that in comparison with the one Lithuanian harbour in Klaipeda and its development rate, Latvia has a few large harbours: Ventspils, Riga, Liepaja. Ventspils is the largest of them. The scope of its activities is the same or even overtakes the scope of the activities of the most harbours of the Baltic Sea region. In 1996, exactly in the harbour of Ventspils more than $80 \%$ of 45 million tons of the loads, which have been processed in the harbours of Latvia, were processed. The harbour of Riga is the eldest harbour of Latvia. It reflects the trading traditions of the state mostly. The harbour of Riga holds the territory of 2530 hectares, its length is about 14 kilometres, and near 60 enterprises develops their activities in its territory. The infrastructure of the harbour has been continuing to form since the $13^{\text {th }}$ century - since the time when the first knowledge about the city of Riga had appeared. The development of the harbour was prompted by Riga becoming the member of Hanza Union. It could be stated, that the consequent harbour development, which was influenced by the environment and socio-cultural traditions, created the conditions for favourable integration of the harbour into the infrastructure of the city. Analysing the situation of the harbour of Klaipeda, it is necessary to notice, that the relation the infrastructure of the harbour with the present net of roads and transport highways is problematic.

It necessary to notice, that the differences of duties of the harbour of Klaipeda, in comparison with the size of duties of the harbours of Ventspils, Riga, Liepoja and Kaliningrad, are inconsiderable. Only Ro-Ro loads and liner ships make an exception. The duties of the harbour of Ventspils exceed the duties of the harbour of Klaipeda more than three times, and the harbour of Riga - more than two times.

\section{The analysis of railroad activities}

The railroad companies of Estonia, Latvia, Byelorussia and Poland are the main competitors of SC "Lietuvos geležinkeliai" in the markets abroad. The international transit makes the main part of the transit via Lithuanian, Latvian, Estonian and Byelorussian railroads. In Poland the local transit makes $70 \%$ of all conveyances. An economical crisis in CIS has influenced the decrease of the transit loads. An unstable Lithuanian policy of duties has decreased the scope of the transit loads from Russia too.

Lithuanian railroad transport has been developed slower (since 1989) in comparison with Latvian and Estonian one. The weaknesses of Lithuanian railroads are: open question of the width of the rut (the width of the rut of most Lithuanian railroads is 1520 millimetres, and only 21,8 kilometres - 1435 millimetres; only 122 kilometres are electrified; an automatical blocking is on the sections of 451,7 kilometres long, and the dispatcher signals - on 135 kilometres; the maximum designed speed for passenger trains is $120 \mathrm{~km} / \mathrm{h}$, and for goods trains $-90 \mathrm{~km} / \mathrm{h}$.

In the future the scopes of the loads transit via Lithuanian railroads will depend on their capability to compete with the railroad companies from the neighbour countries. It is evident, that the harbour of Klaipeda and Lithuanian governmental policy on transit will have a great influence on it.

During 2002 36,6 million tons of loads have been transported via Lithuanian railroads. It is the highest number of loads a year in comparison with eight last years, and more by the quarter $(25,6 \%)$, than in 2001 . The flow of the transit of international loads increased by $32,1 \%$. The rates of the local conveyances were less and increased by $2,2 \%$. An increased flow of the transit loads (especially to Kaliningrad) has a determinant influence on the 
general increase of conveyances of the loads. About $35 \%$ of the loads were conveyed to Kaliningrad (Fig 3).

13,0 million tons of the transit loads were conveyed to Kaliningrad. It made $61,0 \%$ more, than in 2001 . In 2002 the conveyances through the harbour of Klaipeda increased by $13,0 \%$ and it made 7,6 million tons, but the part of transit to the harbour of Klaipeda decreased by $7,9 \%$. The Russian policy of duties still remains the main factor, which has a great influence on the distribution of the flows of the loads between the harbours of Klaipeda and Kaliningrad.

In 2002 the main part $(42,1 \%)$ of the loads, the enterprise has conveyed, was oil and its products. It had been conveyed 15,4 million tons of the products of this kind, and it makes 39,5\% more, than in 2001. The second place (in the general structure of all conveyances) goes to the transit of chemical and mineral manure. In 2002 it has been conveyed 5,2 million tons of these products, and it makes $14,3 \%$ of all the loads conveyed. The conveyances of the ferrous metals are on the third place - it has been conveyed 3,9 million tons of these products, and it makes $10,6 \%$ of all the loads conveyed. It is necessary to notice, that conveyances (via railroads) of the loads of all kinds of products have increased during the analysed period. Only wood makes an exception - the conveyances of it slightly decreased (by $0,6 \%$ ).

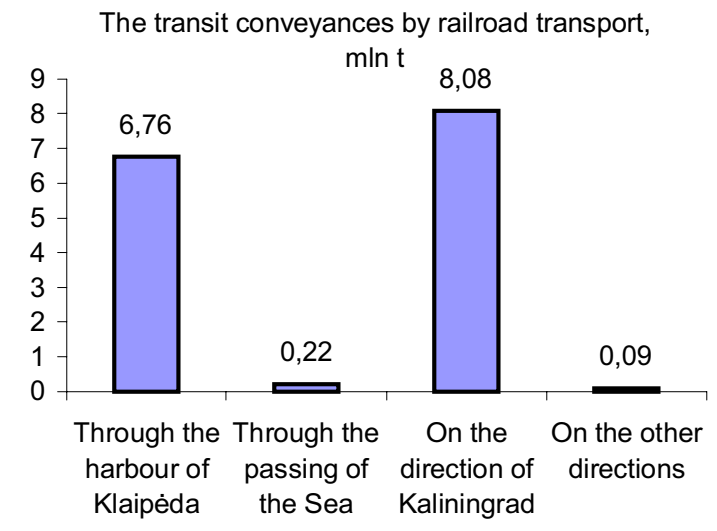

Fig 3. Transit conveyances on general directions in 2002

Evaluating the perspectives of Latvian railroads, it is necessary to notice, that in Latvia a great attention is paid to the investments into the Latvian railroads. It was projected to invest about 280 million of USD into the development of Latvian railroads (itineraries from the harbours of Latvia to the boards of Russia and Byelorussia) infrastructure. Invoking the specific organisations, the projects of the strategic units of the transport are still being prepared. These units will serve the harbours of Ventspils, Riga and Liepaja.

The distance of conveyance via railroad from Riga to Moscow is shorter, than that from Klaipeda to Moscow. Transporting the loads to Russia from the harbours of Latvia, Byelorussia must not be crossed. It is a great competitive advantage.

\section{Competitive advantages and disadvantages}

In comparison with the general potential of Lithuanian transit serving infrastructure, the Latvian one, owning better capacities, has a better situation (it was reflected in the analysis given above). In comparison with the neighbour country, these advantages and defaults of our country must be stressed:

\section{Advantages:}

- The harbour of Klaipeda is non-freezing, while the harbours of Latvia (especially the harbour of Riga) must use icebreakers during cold winters;

- The harbour of Klaipèda has better capabilities of ferries and Ro-Ro loads, which can serve the combined conveyances of goods traffics and railroad carriages as well as some more permanent sea lines of this kind conditionally cheap and safe;

In the harbour of Klaipeda the contemporary modern terminals for the loading of metal and oil products (both of them (especially metal products) have good positions in the international market) are functioning; besides the terminal of Būtinge has the possibilities to take over (from the harbour of Ventspils) a part of the pure oil market;

- In comparison with Latvia, where the preferential rates of duties are not invoked, Lithuania has a more favourable Russian policy concerning the conveyances of the transit loads via railroads;

- There are import and export terminals as well as customs repositories (the client has a possibility to choose), which area is not regulated, in Lithuania. There is no such a possibility to choose in Latvia. Only the customs repositories, which perform the functions of the terminals of import and export, are functioning in it. Besides, the territory of the customs repository must be not less than 5000 square metres in Latvia.

\section{Disadvantages:}

- Lithuania, as distinct from Latvia, does not have a direct connection with the most important consumer of transit services - Russia (it is necessary to cross the intermediary countries - Byelorussia or Latvia; the transit procedures become puzzle as well). Besides the distance from Lithuania to Moscow (the main transit loads generating centre) is longer;

- The harbour of Klaipeda has not the status of an independent harbour yet, while the harbours (which have the status mentioned above since 1996-1997) of Latvia can apply more liberal economical requirements as well as versatile treatment of imposts; 
There is a long functioning terminal of containers in the harbour of Riga. It has its own market and steady clientele. The modern informational system of the containers movement management is introduced in it. The shuttle train Liepaja - Moscow Liepoja is introduced too. Together with Antverpen loading company "Nord Natic", which has good positions in an international market of containers transit, the terminal of the containers was built in Ventspils. Unhappily the harbour of Klaipeda has no powerful partners for the business of the containers yet. For lack of demand the traffic of the shuttle train "Baltic Express" is not opened, and "Vikingas" is functioning very heavily;

- A big terminal of kalium manure loading (an annual capacity is 5,0 millions tons) and powerful units (about 30 millions tons a year) of oil and its products is functioning in Ventspils; the last mentioned are served not only by railroads, but by the pipeline. It is reloaded two times less, than in the harbour of Ventspils, of different manure in the harbour of Klaipeda, and only via railroad delivered oil products (not counting the pure oil) - about 3,5 times less;

- The depth of the boundaries of the harbour of Ventspils reaches $17,5 \mathrm{~m}$ (the ships up to 130 thous. dwt. can be harboured), while in the harbour of Klaipeda only ships up to 60 thous. dwt. can be harboured near the boundaries of 12 metres depth;

- The physical situation of the net of the roads and railroads in the territory of the harbour of Klaipeda, its premises and serving stations are bad, therefore it can not secure the clear interaction between land and harbour transport infrastructures;

- An entrance of the ships to the Klaipedas harbour as well as harbouring during the storms is unsafe for the lack of the infrastructure of the gates of the harbour;

- In Riga the harbour for passengers, which can harbour huge cruise liners, exists for a long time, while Klaipèda terminal for cruise liners was opened only in 2002. The passengers serving infrastructure is not introduced yet;

- The technical situation of Lithuanian transit serving railroads (the construction of the roads, signals and the system telecommunications) stands behind the Latvian one;

- In Lithuania the fixed period of goods storage at the terminals of import and export is 45 days (with the possibility to extend it to 90 days, if the necessity of such extension will be proved). The goods can be stored for a year in Latvia;
The goods without necessary documents are not allowed in the territory where the customs of the Republic of Lithuania are active. In Latvia the goods can be placed in the customs repositories until the necessary document is collected;

- In comparison with the analogous order in Latvia, there is a inflexible system of guaranties of import and export in the terminals and customs repositories in Lithuania;

- It is illegal (as distinct from Latvia) to convey the goods, which are exported at the terminals of import and export, from one to another terminal as well as to change the recipient of imported goods in Lithuania.

\section{The most important strategic directions of the de- velopment of transit by Lithuanian water and rail- road transport}

Evaluating the changes of nomenclature of the loads flows, it is necessary to apply the sector of transit services to the processes of the international trading market. An orientation to the services for the different types of goods provides the possibility to enlarge the scopes of transit as well as to look for the new markets of transportation. After the evaluation of present situation of the transit business system, the most important noteworthy directions, which are necessary to improve, could be these:

- The modernisation of the Klaipedas harbour infrastructure by building new and reconstructing the existing boundaries, deepening the water area up to 14 metres as well as reconstructing the infrastructure the harbours mouth. The stimulation of the clients from abroad to invest into the infrastructure of the harbour as well as the security of the stability of the flows and attraction of the expeditionary and navigation companies, which have their own terminals of transit loads (especially containers) to the harbour of Klaipèda;

- The modernisation of the net of Lithuanian railroads by the overhaul of the railroad lines, which are the part of the $9^{\text {th }}$ international corridor of transport (Klaipèda - Šumsk and Kaišiadorys - Kybartai) as well as modernising the equipment of telecommunication and signalisation. The improvement of the infrastructure of the $1^{\text {st }}$ railroad corridor as well as the marketing activities in order to attract the flows of the loads to (from) Western and Central Europe „growing“ the demand for the future railroad (correspondent to European standards) line from the border of Poland to Kaunas and from it to the direction of Latvia; 
- The improvement of the Klaipeda harbour interaction with other transport branches by the modernisation of approach roads and railroads infrastructure;

- The exploitation of the possibilities, which give the status of an independent harbour, as well as the liberalisation of the transit business by creating the conditions for the through movement of goods and simplifying the formality of the inspection, storage, and transportation of the goods in all the territory of the state;

- The continuous development of the international net of linear navigation;

- The adoption of a flexible system of the rates of harbour charges, the loading and storage as well as the transportation through the territory of Lithuania;

- The simplification and improvement of the legal basis and the system of guarantees, which regulate the performance of the transit procedures in order to accelerate the execution of documentation;

- The creation of the system of state support and stimulation of the combined transport development. It is necessary to formulate the requirements (in accordance with the appropriate directives of the EU), which would stimulate the private initiatives and would let to attract the investments for the development of combined transport as well as for the foundation of the logistics centres, which have a great importance for the development of international conveyances in the future;

- The development of international relations and intergovernmental agreements by the improvement of the process of delivery of the goods in accordance with the requirements of international conventions;

- The foundation of centres and terminals of the logistics, securing the guaranties for stable activities of the businessmen, who are willing to develop the services of the logistical deliverance of the goods;

- The creation, improvement and integration of the informational systems of transport branches, also securing the possibility to detect the location of the load at every moment as well as gathering the complete statistical information concerning the transit conveyances are being preceded;

- The activating of the marketing activities by looking for the new transportation markets as well as forming an image of Lithuania as owning a high developed transport system and favourable for the transit country.

\section{Conclusions}

1. In comparison with Lithuanian system of transit transport, Latvian one has competitive advantages, which are determined by the historical and trading relations, infrastructure, socio-cultural environment and traditions as well as the favourable integration with other systems of transport.

2. It is necessary to pay attention to the preferred strategic directions for the development of the transit services as well as to solve (on the governmental level) the questions of competition choosing the cooperation policy of Lithuanian and Latvian systems of transit transport.

3. On the ground of the accomplished analysis the underlying questions of the development of transport system were defined:

a) the improvement of the present Lithuanian systems of transportation and integration of infrastructure;

b) the adoption of the appropriate legal basis in order to encourage and support the business of transit services;

c) the reasoning of the expediency to invest into the transport infrastructure.

4. The development and competitiveness of both Lithuanian and Latvian systems of transit transport should be adjusted after the gaining of the EU membership.

\section{References}

1. Fiquet, C. Intermodal transport can solve Europe's transport problems. European railway review, 1999, No 5/1.25 p.

2. Newmanand, A. M.; Yano, C. A. Scheduling Direct and Indirect Trains and Containers in an Intermodal Setting. Transportation Science, 2000, Vol 34, p. 220-270.

3. Šakalys, A.; Jaržemskis, V.; Zubkevičius, A. The New Way towards Europe. In: Transport. Harbours. Logistics (Транспорт. Порты. Логистика). Riga: An Informational Centre of the Transport, 2000, 1999, No 16, p. 40-42 (in Russian).

4. Mačiulis, A.; Palšaitis, R. The Shaking-up of the Railroads and the Development of the Multimodal Conveyances. Researches of VGTU. Transport (Transportas), 1997, No 1(14), p. 9-14 (in Lithuanian).

5. Palšaitis, R.; Burkovskis, R. Analysis of cargo and passengers transportation tendencies in the Lithuanian railway system. Transport (Transportas), 1999, Vol 14, No 2, p. 55-61 (in Lithuanian).

6. Palšaitis, R. Transit Transport: the Influence on the Intensity of the Traffic and on the Development of the Economics of the State. In: Transport: Technologies, Economics, Environment, Health (Transportas: technologijos, ekonomika, aplinka, sveikata). Vilnius: Technika, 2003, p. 152-204 (in Lithuanian). 